\title{
Cell Biological Changes of Outer Cortical Root Cells in Early Determinate Nodulation
}

\author{
Paulina C. van Spronsen, Mette Grønlund, Cristina Pacios Bras, Herman P. Spaink, and Jan W. Kijne \\ Institute of Molecular Plant Sciences, Leiden University, Wassenaarseweg 64, 2333 AL Leiden, \\ The Netherlands \\ Submitted 14 December 2000; Accepted 9 March 2001.
}

In the symbiosis of leguminous plants and Rhizobium bacteria, nodule primordia develop in the root cortex. This can be either in the inner cortex (indeterminate-type of nodulation) or outer cortex (determinate-type of nodulation), depending upon the host plant. We studied and compared early nodulation stages in common bean (Phaseolus vulgaris) and Lotus japonicus, both known as determinatetype nodulation plants. Special attention was paid to the occurrence of cytoplasmic bridges, the influence of rhizobial Nod factors (lipochitin oligosaccharides [LCOs]) on this phenomenon, and sensitivity of the nodulation process to ethylene. Our results show that i) both plant species form initially broad, matrix-rich infection threads; ii) cytoplasmic bridges occur in $L$. japonicus but not in bean; iii) formation of these bridges is induced by rhizobial LCOs; iv) formation of primordia starts in $L$. japonicus in the middle root cortex and in bean in the outer root cortex; and $v$ ) in the presence of the ethylenebiosynthesis inhibitor aminoethoxyvinylglycine (AVG), nodulation of $L$. japonicus is stimulated when the roots are grown in the light, which is consistent with the role of cytoplasmic bridges during nodulation of $L$. japonicus.

In the symbiosis between leguminous plants and Rhizobium spp. bacteria, nitrogen-fixing nodules develop on plant roots. In many cases, this process is preceded by the induction of root hair curling during bacterial colonization of the root surface. Via infection threads growing from root hair curls, the bacteria migrate into the root cortex, where concomitantly nodule primordia develop. A nodule primordium can be formed either in the inner cortex (indeterminate-type nodulation) or in the outer cortex (determinate-type nodulation), depending upon the host plant (Brewin 1991; Hirsch 1992).

In indeterminate-type nodulation such as with pea and vetch, the bacteria in the infection thread have to pass from cell to cell to reach the primordium in the inner root cortex. Formation of infection threads is preceded by the formation of preinfection thread structures in the vacuolated outer cortical cells. These consist of a series of radially orientated, conical cytoplasmic columns, also know as "cytoplasmic bridges." Cytoplasmic bridges are essential for a successful indeterminate-type nodulation process (Bakhuizen 1988; Kijne 1992). Their formation is induced by rhizobial Nod factors (lipo-chitin oligosaccharides

Corresponding author: P. C. van Spronsen; Fax +31 715274999

E-mail: spronsen@ rulbim.leidenuniv.nl
[LCOs]), which are secreted by rhizobia (Van Brussel et al. 1992; Van Spronsen et al. 1994). Passage of the infection thread through the outer cortical cells occurs opposite the axis of the cytoplasmic bridges and is accompanied by local cell wall modification and degradation (Bakhuizen 1988; Van Spronsen et al. 1994). This gives the impression of hypha-like growth. An infection thread, however, is a composite structure formed by neighboring host cells.

In determinate-type nodulation such as with soybean and common bean, a long passage through the outer cortex is not required. The bacteria in the infection thread quickly reach the primordium in the outer cortex, which is situated in the direct vicinity of the infected hair. Studies of the (early) determinatetype nodulation process have been performed with soybean (Calvert et al. 1984; Newcomb et al. 1979; Turgeon and Bauer 1982; Turgeon and Bauer 1985), common bean (Rae et al. 1992; Taté et al. 1994; Vandenbosch et al. 1985), siratro (Ridge and Rolfe 1986), Sesbania spp. (Ndoye et al. 1994), and L. japonicus (Szczyglowski et al. 1998). Most of these studies, however, concern the infection process in the root hair and/or nodule development, rather than the early morphological events in the root cortex.

In the interaction of rhizobia and vetch (Vicia sativa subsp. nigra), an indeterminate-type nodulating plant, the thick short root (Tsr) phenotype develops when nodulating roots are grown in the light (Van Brussel et al. 1982). Such roots have a reduced length and, locally, are twice as thick as normal roots. Nodulation is delayed, and nodules are not formed on the main root, only at sites of lateral root emergence (Zaat et al. 1989). LCOs induce the biosynthesis of ethylene, but vetch roots grown in the light respond with an overproduction of ethylene. As a result, formation of cytoplasmic bridges is inhibited and the nodulation process is aborted (Van Spronsen et al. 1995). Addition of the ethylene biosynthesis-inhibitor aminoethoxyvinylglycine (AVG) restores normal root morphology and the nodulation process.

Until now, the formation of cytoplasmic bridges has not been studied for determinate-type nodulation and little is known about the very early nodulation stages in the outer cortical cells of the plants concerned. We studied these early stages in Phaseolus vulgaris (common bean) and Lotus japonicus, both determinate-type nodulation plants, after infection by the appropriate rhizobia. We started from a working hypothesis that the formation of cytoplasmic bridges and broad infection threads are necessarily correlated with the relatively long infection pathway during indeterminate nodulation, in contrast to the situation during determinate nodula- 
tion. Additionally, in L. japonicus, we studied the early responses of the root cortex after incubation with LCOs. Special attention also was paid to the sensitivity of the nodulation process to ethylene. The results were compared with earlier studies of indeterminate-type nodulation such as with Pisum sativum and $V$. sativa and the LCO responses with $V$. sativa (Bakhuizen 1988; Kijne 1992; Van Brussel et al. 1992; Van Spronsen et al. 1994).

\section{RESULTS}

\section{Early nodulation stages in $\boldsymbol{P}$. vulgaris cv. Negro Jamapa.}

At 5 to 7 days after inoculation with wild-type Rhizobium etli, roots from common bean (P. vulgaris cv. Negro Jamapa) show many activated zones. Nodule primordia in all stages of development can be found on the lateral roots. Often, several root hairs close to, or even next to, each other were shown to be infected, resulting in the presence and even clustering of several nodules on the same part of the root. Curled infected root hairs were usually short and thick, with a thick cell wall, and contained broad (i.e., showing several bacteria side by side), matrix-rich infection threads. The threads often ramified into multiple broad threads while still present inside the hair. These multiplied infection threads appeared to penetrate the hair cell wall at the root hair base at several places and in several directions. In front of the infected hair(s), the cells in the root cortex were activated. Swollen nuclei migrated to the cell center and the cells divided.

Significantly, the first cell divisions could be seen in the first cortical cell layer, whereas the other cortical cell layers later divided. All together, they gave rise to a nodule primordium. The parental cortical cells from which the primordial cells originated initially could still be distinguished. Usually, the first cell divisions were in a radial direction, with later cell divisions occurring in other directions. The activated cells contained large nuclei with distinct prominent nucleoli.

Close observation revealed that divisions in front of an infected hair in very young primordia do not happen randomly. Young divided cells often formed a column of cells. A series of transverse, nonconsecutive semithin sections through the root cortex showed a nodule primordium at a very early stage (Fig. 1A to C). The cells directly in front of the hair polarized and formed two columns. Cytoplasmic bridges were not formed, and the swollen nuclei were situated in the center of the cells in thin cytoplasmic strands. The broad, ramified infection thread in the hair (Fig. 1A) penetrated these cell columns (Fig. 1B and C). Abundant cell divisions in the outer cortex followed infection of two adjacent infected root hairs
(Fig. 1D). In the inner cortex, the cells made single radial divisions. Also, in the case of more infected hairs, a column of cells often formed (Fig. 1E, which is a larger magnification of a nonconsecutive section of the left root hair in Fig. 1D, with a small part of the infection thread still showing, as well as the underlying cells.) These cells formed a polarized column with swollen nuclei in their center. Figure $1 \mathrm{~F}$ shows a more advanced stage of nodule development and the infection thread growing into a column of cells.

Penetration of the cell wall by the broad infection thread at the base of the root hair may extend over a large area, involving several cells at the same time. Figure $1 \mathrm{G}$ shows a part of the root hair base, where a broad thread crossed the hair cell wall to enter two adjoining divided cortical cells. While the thread continues its way deeper into the cortex, it branches into multiple threads (Fig. 1G), which become more and more narrow. These thinner threads enter the surrounding meristematic cells in all directions. This can happen at several places in the same cell wall (Fig. 1H). Bacteria were not released into the first dividing cells of the primordium in the outer cortex but were still surrounded by an infection thread wall (Fig. 1G). Numerous mitochondria were present in the infection thread area (Fig. $1 \mathrm{G}$ and $\mathrm{H}$ ) (Cermola et al. 2000).

\section{Early nodulation stages in $L$. japonicus.}

At 7 to 10 days after inoculation with wild-type Mesorhizobium loti, L. japonicus roots showed many activated zones distributed over the whole root. Close to the hypocotyl, mature nodules were present, whereas further toward the root tip nodule primordia were found. Curled root hairs contained very broad, matrix-rich infection threads. Multiple, thin branches in all directions (Fig. 2A) characterized such threads.

The root cortex consisted of four cell layers with vacuolated, elongated cells, which were triggered to respond in front of the infected root hair. The swollen nuclei migrated to the center of the cells. Cells of the outer cortex that were directly in front of the hair did not divide but polarized with the cytoplasm rearranged in a radial direction, resulting in the formation of cytoplasmic bridges. A series of transverse, nonconsecutive semithin sections through the root cortex in front of the infected hair at a very early stage of nodule development showed cytoplasmic bridge development (Fig. 2B to E). The hair (Fig. 2B) and the first cortical cell (Fig. 2C and D) contain an infection thread. The second cortical cell contains a mature cytoplasmic bridge (Fig. 2C), and the third cortical cell contains a cytoplasmic bridge in an earlier stage of development (Fig. 2E). Cytoplasmic bridges usually develop in the

\footnotetext{
Fig. 1. Transverse sections through the root cortex of Phaseolus vulgaris cv. Negro Jamapa inoculated with wild-type Rhizobium etli bacteria. A-F, Light micrographs of semithin sections. G and H, Electron microscopical sections. rhb, root hair base; v, vacuole; n, nucleus; cw, cell wall. A-C, Serie of nonconsecutive sections through a part of the root cortex in front of the infected hair showing a nodule primordium at a very early stage. A, Curled root hair contains a ramified broad infection thread. A-C, The first cortical cell divided and formed two columns of polarized cells directly in front of the hair, with swollen nuclei in the center. B and C, Infection thread grows through both columns (arrows). D, Young primordium showing the abundant cell divisions in the outer cortex in front of two infected root hairs (arrows). In the inner cortex, there are only single radial divisions. E, Larger magnification of the same primordium and left hair as in $\mathbf{D}$, in a nonconsecutive section. A very small part of the infection thread in the hair is still visible, indicated by an arrow. In front of the hair, a polarized column of cells has formed with swollen nuclei in their center. F, More advanced stage of nodule development. Root hair containing a broad infection thread that has grown into the underlying column of cells (arrows). G, Root hair base and underlying divided cortical cells into which a very broad infection thread has grown and branched into thinner threads (arrows) surrounded by an infection thread wall. H, Further into the nodule primordium, the thinner threads have branched and crossed the same cell wall at several places. Bar $=25(\mathbf{A}-\mathbf{F})$, $2.5(\mathbf{G})$, and $1 \mu \mathrm{m}(\mathbf{H})$.
} 
A
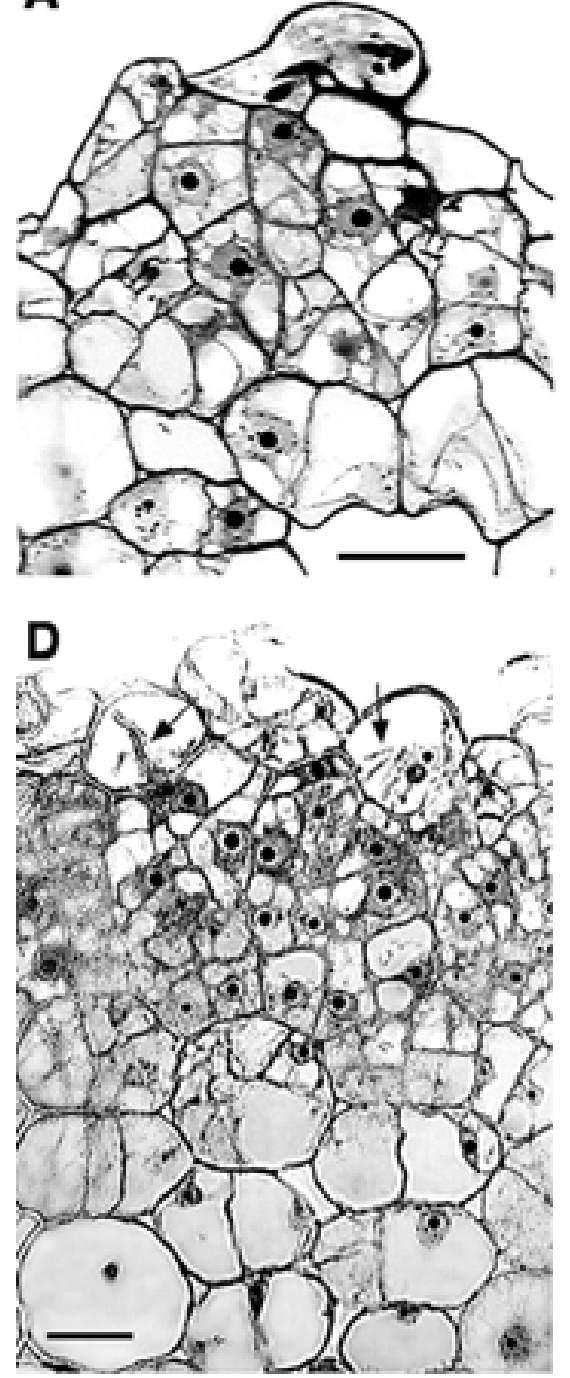

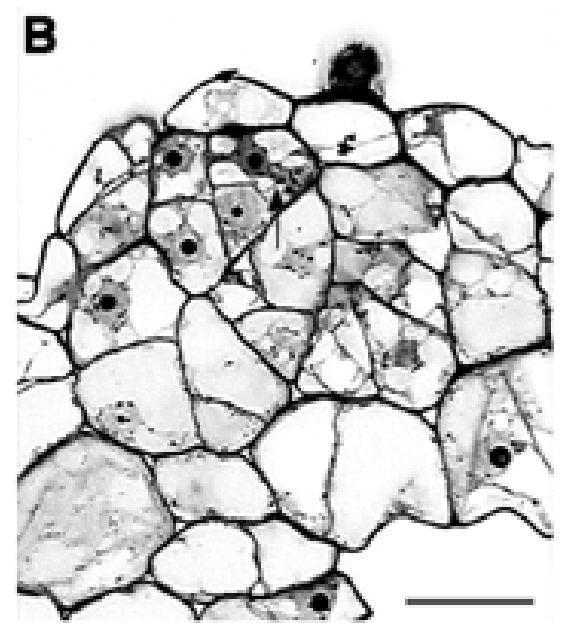

E

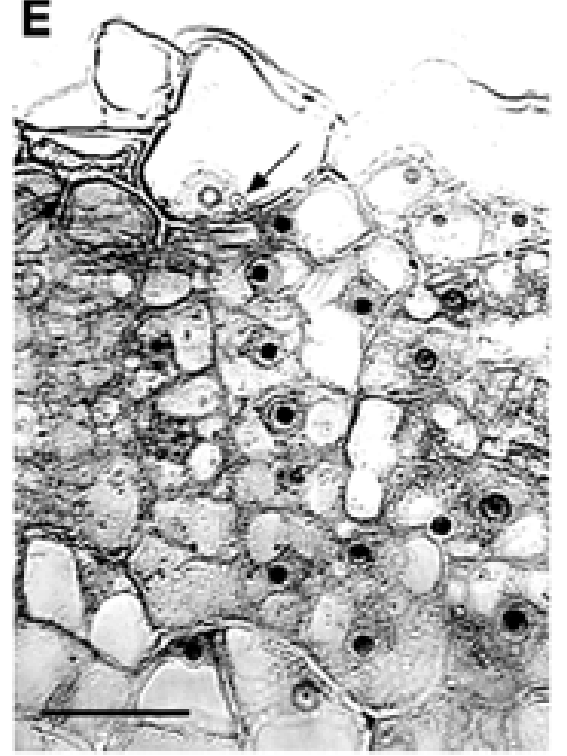

C
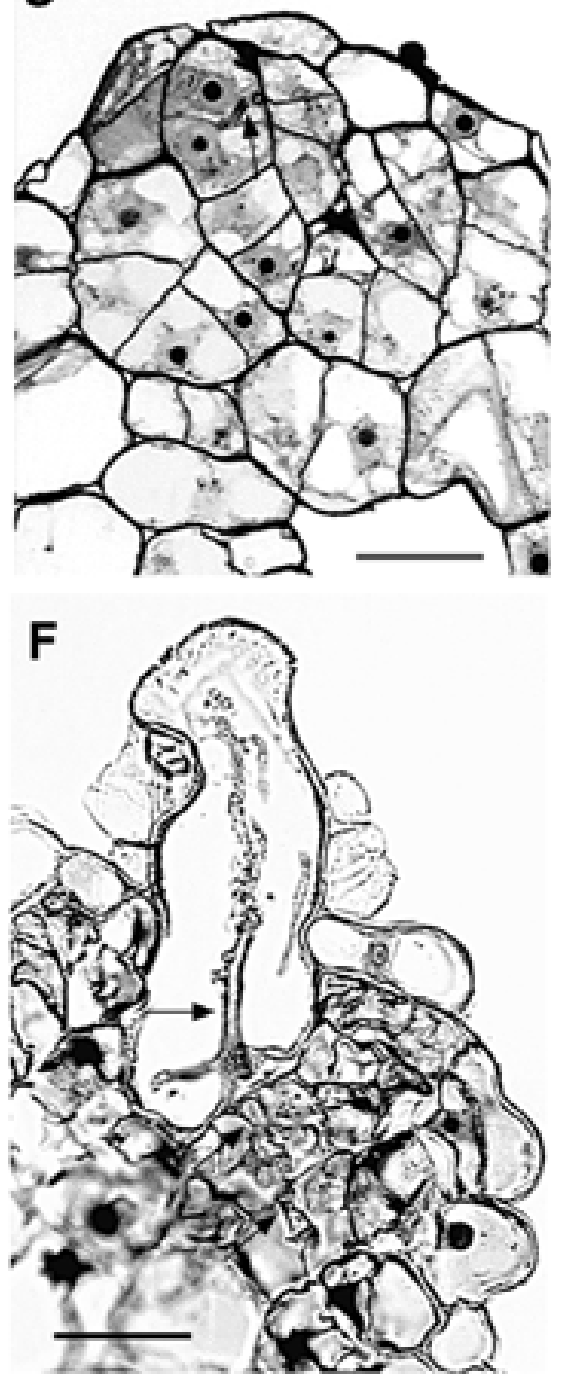
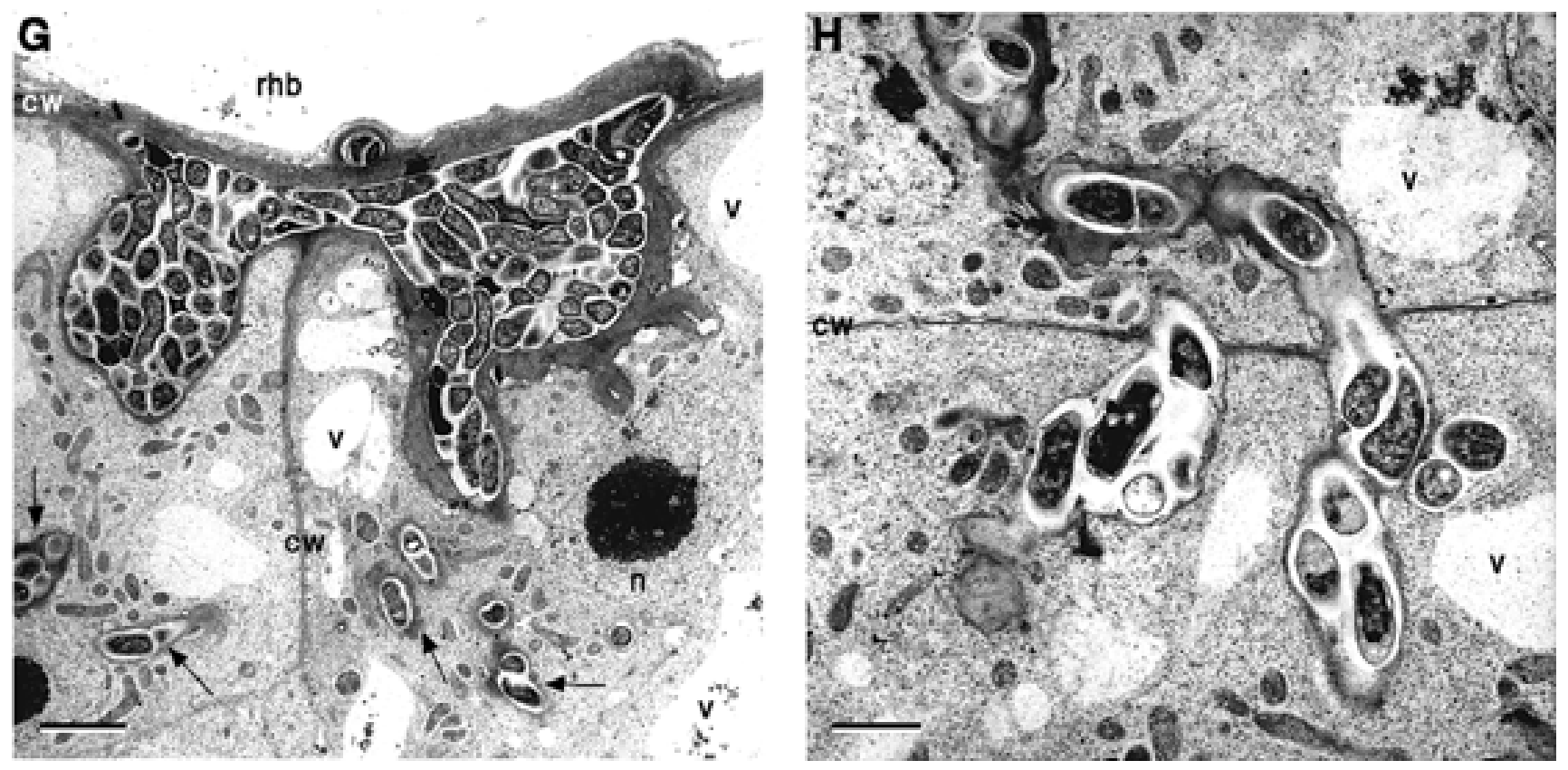
first and second cortical cell layer (Figs 2C and F) but sometimes could be found in the third layer (Fig. 2E). The approaching broad infection thread can grow through these bridges (Fig. $2 \mathrm{~F}$ and $\mathrm{G}$ ).

The first cortical cell layer either did not divide at all (Figs. $2 \mathrm{~B}$ to $\mathrm{H}$ and $\mathrm{J}$ ) or made one radial division at the most (Fig. 2I). This situation persisted during development of the root nodule (data not shown). The second cortical cell layer may eventually divide. If so, the cells polarized after few divisions and formed a column of cells, which were more vacuolated than the surrounding meristematic cells. These cells also contained cytoplasmic bridges, through which the broad infection thread grew (Fig. 2G), and remained in a vacuolated state, whereas surrounding cells continued dividing (Fig. $2 \mathrm{H}$ and I). Additionally, a broad infection thread grew straight into a column of vacuolized cells surrounded by the small cytoplasm-rich cells of the young primordium (Fig. $2 \mathrm{H}$ ).

A broad infection thread may branch in a radially divided cell of the first cortical layer (Fig. 2I). One branch of the infection thread passes through the radial cell wall, whereas the other grows straight on it. This results in two columns of polarized, vacuolated cells surrounded by young meristematic cells (Fig. 2I).

Usually the third cortical cell layer gave rise to the first cell divisions, leading to the formation of a nodule primordium (Fig. 2F and J). Figure 2J shows a part of the young primordium that was not directly in front of the infected hair. It was clearly seen that cells of the third layer made numerous divisions. Cells of the first layer made none and, in the second layer, only one radial division was seen. Cells of the fourth layer and surrounding cells in the second and third layer just started to divide (Figs. 2F and J). The shape of the maternal cortical cells from which the divided cells originated was still visible. Activated cells have large nuclei with distinct prominent nucleoli.

Broad infection threads appeared to grow further into the nodule primordium by crossing cell walls. During this process, an initially broad thread branched into more and more narrow threads to enter the surrounding meristematic cells in all directions (Szczyglowski et al. 1998).

\section{Early cortical responses in $L$. japonicus after treatment with LCOs.}

At 4 to 6 days after inoculation with LCOs, roots of $L$. japonicus showed activated zones distributed over the root. The first responses of the cortical cell layers were similar to those described for nodulation, resulting in the formation of cytoplasmic bridges in the first (Fig. 3A) and second cortical cell layers. The absence of bacteria and, consequently, the absence of infection thread growth induced the cells containing cytoplasmic bridges to develop cortical root hairs (Van Brussel et al. 1992; Van Spronsen et al. 1994). This process takes place relatively quickly after the bridges are formed. A first-layer cortical cell containing a cytoplasmic bridge developed a cortical root hair, "pushing" its way out between two epidermal cells (Fig. 3B).

After cortical root hair formation, the underlying cortical cells are activated to form a primordium. A young activation zone (Fig. 3C), similar to that shown during rhizobial infection (Fig. 2F), was observed. A cell of the third cortical cell layer divided, the surrounding cells were activated, and the outer cells developed cortical root hairs.

The second cortical cell layer, similar to nodulation, may or may not divide. In the latter case, these cells also develop cortical root hairs. Figure 3D shows both cases next to each other. The cell at the left of the figure did not divide and developed a cortical root hair, whereas the cell at the right did divide and contains a young cell wall.

Prolonged exposure to LCOs caused cortical root hairs to grow considerably (data not shown) and swell (Fig. 3C, D, and F). Eventually, cells of the inner cortex formed a primordium with cortical root hairs still present at the outside (Fig. 3E and F). This primordium may reach a substantial size (Fig. 3F).

\section{Nodulation and ethylene.}

With common bean, almost without exception, nodules were formed on the lateral roots. Remarkably, some lateral roots were completely covered with mostly clustered nodules in several stages of development, whereas other lateral roots on the same plant did not show nodules at all. In roots grown in the light, formation of nodules was delayed or inhibited and large nodulation variations between plants could be observed. Development of the Tsr phenotype, however, did not occur. Interestingly, the addition of the ethylene-biosynthesis inhibitor AVG slightly increased rather than inhibited the delay in nodule formation and nodulation variations. This effect was reversed when the roots were grown in the dark. In this case, nodule growth was more regular in the presence of AVG. These results indicate that the role of ethylene in bean infection is different from that in vetch infection, which is consistent with the absence of cytoplasmic bridges in the infection process.

Fig. 2. Light micrographs of transverse semithin sections through the root cortex of Lotus japonicus inoculated with wild type Mesorhizobium loti bacteria. A, Curled root hair containing a broad, matrix-rich infection thread that makes multiple thin branches in all directions. B-E, Series of nonconsecutive sections through a part of the root cortex in front of the infected hair showing a very early stage of nodule development and the development of cytoplasmic bridges. B, Curled root hair contains an infection thread, which penetrated into C and D, the first cortical cell (arrows). B-D, Second cortical cell contains a mature cytoplasmic bridge and no infection thread. E, Third cortical cell contains a cytoplasmic bridge in an earlier stage. The other cortical cells show hardly any response. F, More advanced stage of root infection. A broad infection thread grew from the infected hair through the cytoplasmic bridges in the first and second cortical cell. The third cortical cell made the initial divisions for the formation of the primordium. The surrounding cells are activated. G, Young nodule primordium, where the first cortical cell layer is undivided, containing an infection thread through a cytoplasmic bridge. The second cell layer divided and formed a column of polarized cells containing cytoplasmic bridges with infection threads (arrows). $\mathbf{H}$, Nodule primordium consisting of small cytoplasm-rich cells that surround a column of vacuolated cells containing an infection thread. The first cortical cell contains a thread (arrow) and has not divided. I, Nodule primordium where the first cortical cell made one radial division, the infection thread branched, and the second cortical cell layer made two columns of polarized, vacuolated cells (indicated with asterisks), through which the infection threads grow. Young meristematic cells surround these columns. J, Part of a young nodule primordium in an area not directly in front of the infected hair, showing that the initial formation of the primordium has started in the third cortical cell layer. The first cell layer made no divisions, the second made one, and the surrounding cells made several. Original shape of the maternal cortical cells is still visible. Bar $=10(\mathbf{A}), 25(\mathbf{B}-\mathbf{G})$, and $50 \mu \mathrm{m}(\mathbf{H}-\mathbf{J})$. 
In contrast to the situation with bean, L. japonicus roots grown in the absence of AVG developed the Tsr phenotype, even when the lower half of the petri dish was shielded from light. The roots showed a reduced length and, locally, were approximately twice as thick as normal roots. Nodules formed on the main root and, in later stages, could develop at sites where lateral roots emerged, although nodulation was delayed and strongly inhibited. The addition of AVG to the growth medium restored normal root growth in the light and restored the nodulation process, with developing nod-
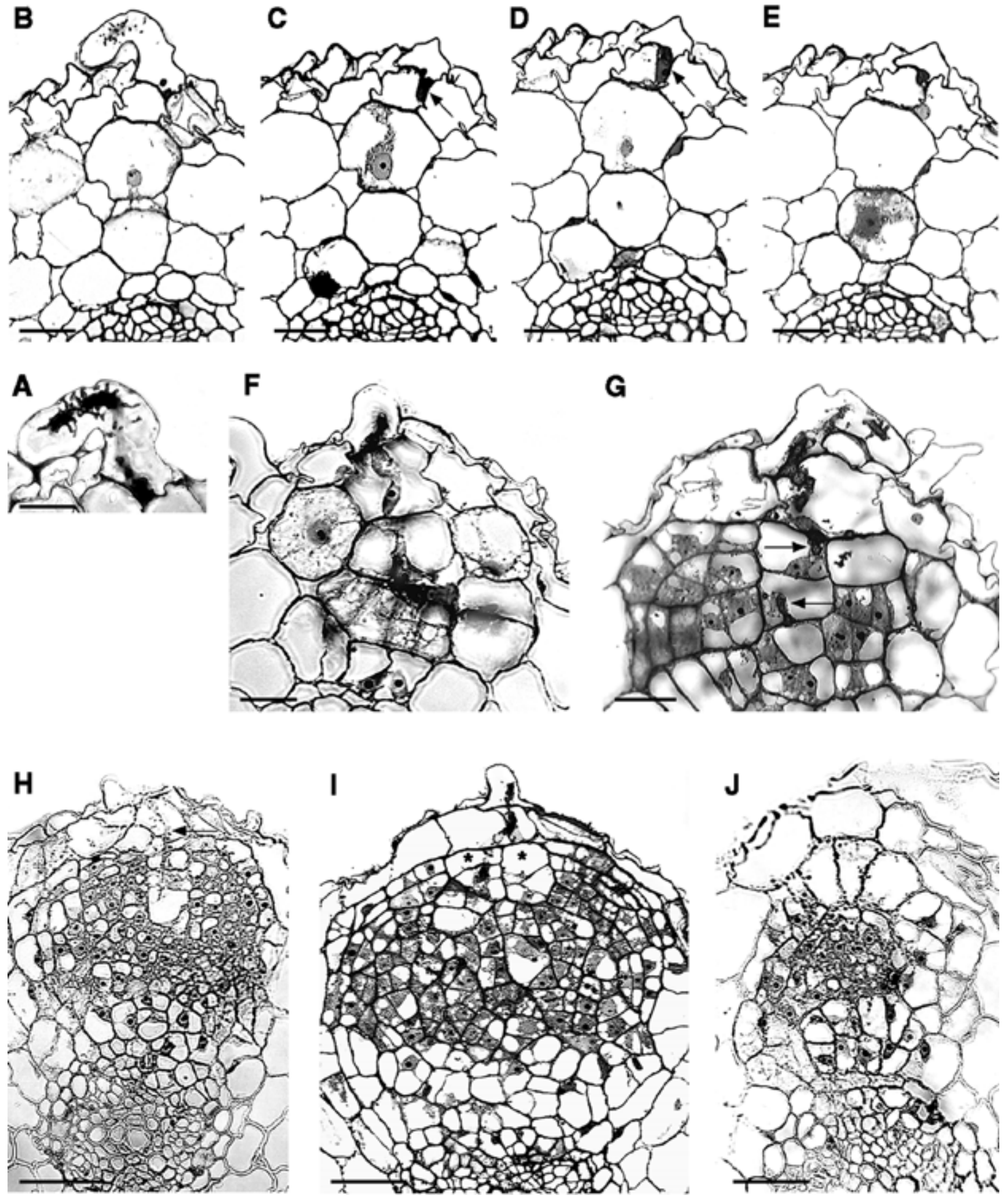
ules distributed over the whole root as a result (Pacios Bras et al. 2000). These results are similar to those obtained with vetch. Apparently, excessive ethylene formation during root growth in the light inhibits the nodulation process in $L$. japonicus, with the formation of cytoplasmic bridges as one probable target.

\section{DISCUSSION}

In this study, we compared early changes in the outer root cortex after infection by rhizobia of $P$. vulgaris and L. japonicus. Although both plants are known as determinate-type nodulation plants, and some similarities in the nodulation process were found, considerable differences in the early development of nodule primordia in the outer cortical cells were observed. Our results show that i) both species initially show broad, matrix-rich infection threads; ii) cytoplasmic bridges occur in L. japonicus but not in common bean; iii) formation of these cytoplasmic bridges is induced by rhizobial LCOs; iv) the formation of primordia starts in L. japonicus in the middle root cortex and, in bean, in the outer root cortex; and $\mathrm{v}$ ) in the presence of the ethylene-biosynthesis inhibitor AVG, nodulation of $L$. japonicus is stimulated when the roots tion of L. japonicus is stimulated when the roots are grown in light, in contrast to bean. The nodulation situation of bean is similar to that of soybean in which the first cell divisions also occur in the first outer cortical cell layer, with the sensitivity to ethylene still being a matter of debate (Ligero et al. 1999; Schmidt et al. 1999). Nodulation of L. japonicus suggests an intermediate situation, with early stages similar to those in indeterminate-type nodulation plants and later stages similar to those in determinate-type nodulation plants (Fig. 4). The sensitivity of L. japonicus nodulation to ethylene is consistent with the role of cytoplasmic bridges during infection because ethylene inhibits their formation (Van Spronsen et al. 1995).

Broad, matrix-rich infection threads usually have been associated with indeterminate-type nodulation and correlated with a longer passage of the bacteria through the cortex on their way to the nodule primordium (Kijne 1992). Our observations show and confirm that determinate-type nodulating plants such as L. japonicus (Szczyglowski et al. 1998) and bean also form broad infection threads. In L. japonicus, the broad thread may pass a number of polarized vacuolated cells containing cytoplasmic bridges, whereas in bean the broad thread is mostly in the vacuolated root hair. Therefore, the
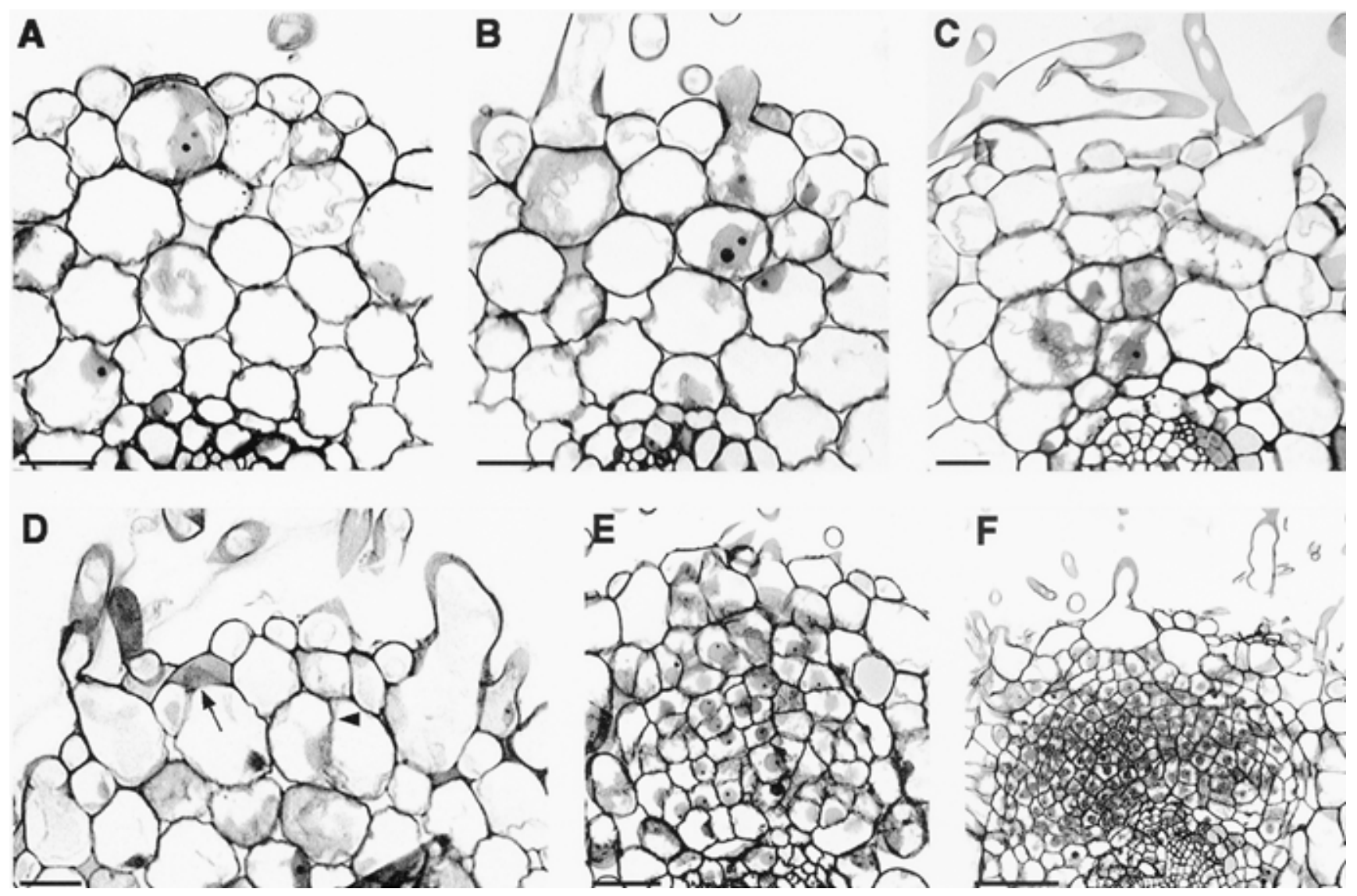

Fig. 3. Light micrographs of transverse semithin sections through the root cortex of Lotus japonicus treated with lipochitin oligosaccharides (LCOs) of Mesorhizobium loti. A, Part of the root cortex at a very early stage of LCO-induced response. The first cortical cell contains a mature cytoplasmic bridge. B, Cell from the first cortical layer containing a cytoplasmic bridge and, in the process of developing a cortical root hair, "pushing" its way out between two epidermal cells. C, Young activation zone with a cortical root hair in the first cell layer. Cells in the third cortical cell layer made an initial division for the formation of the primordium. The surrounding cells are activated. D, Part of the outer cortex showing well-developed swollen cortical root hairs in the first layer. In the second cortical cell layer, the cell at the left did not divide and is developing a cortical hair (arrow). The cell at the right divided and contains a young cell wall (arrowhead). E, Young primordium with several cortical root hairs in the outer layer. F, Primordium at a more advanced stage of development with cortical root hairs in the outer layer. Bar $=25(\mathbf{A}-\mathbf{D}), 50(\mathbf{E})$, and $100 \mu \mathrm{m}(\mathbf{F})$. 
state of vacuolization of a host plant cell apparently determines the type of infection thread (broad or narrow) rather than the type of nodulation (indeterminate or determinate).

As far as we know, cytoplasmic bridges have not yet been described for a determinate-type nodulating plant. Our results show that in L. japonicus, their formation precedes infection thread formation with several layers of vacuolated cells to be crossed by the bacteria to reach a primordium. This situation is similar to that described for the indeterminate-type nodulating pea and vetch (Fig. 4A) (Bakhuizen 1988; Kijne 1992; Van Brussel et al. 1992; Van Spronsen et al. 1994) and alfalfa (Timmers et al. 1999). Likewise, in L. japonicus, changes in the root cortex, including the formation of cytoplasmic bridges, cortical root hairs, and nodule primordia are induced by LCOs, as described for V. sativa (Van Brussel et al. 1992; Van Spronsen et al. 1994). Cortical cells containing cytoplasmic bridges develop cortical root hairs in the absence of infection thread growth. This process appears to occur rather quickly, and bridge-containing cells rarely are found after cell divisions have been initiated in the cortex. Van Brussel et al. (1992) proposed that cell polarization in the outer root cortex is determined by endogenous gradients of both plant growth factors and rhizobial stimuli, in accordance with the gradient hypothesis for root nodule initiation (Libbenga et al. 1973). Such gradients may determine which cortical cells start to divide and which cortical cells, after activation, become arrested in the cell cycle and polarize to form a cytoplasmic bridge (Bakhuizen 1988; Yang et al. 1994). Careful analysis of the local expression of specific stimuli-responsive genes may identify gradient differences between common bean and $L$. japonicus.

An intermediary situation between indeterminate- and determinate-type nodulation, essentially as we found for $L$. japonicus, also has been described for root nodules of the semiaquatic Sesbania rostrata (Ndoye et al. 1994). Fernández-
López et al. (1998) found that the outcome of this process was dependent upon environmental conditions and influenced by ethylene. Determinate nodules were formed in the presence of ethylene and indeterminate nodules in the presence of an ethylene inhibitor. In contrast, the land plant L. japonicus formed determinate nodules in the presence of AVG. The nodulation response of $S$. rostrata to ethylene may be correlated with its adaptation to semiaquatic conditions, enabling it to adjust the gradients of growth factors, depending upon the growth conditions. In other legumes such as L. japonicus and common bean, these hypothetical gradients may be fixed, resulting in a determinate-type nodulation under all conditions.

\section{MATERIALS AND METHODS}

\section{$P$. vulgaris plants and bacteria.}

Seeds of common bean, $P$. vulgaris cv. Negro Jamapa (a gift from F. Sánchez, Cuernavaca, Mexico), were washed in sterile water and surface sterilized in ethanol $(96 \%)$ for $5 \mathrm{~min}$. Three consecutive washings in sterile water were followed by a treatment in $2 \%$ commercial bleach for 3 min, three washings in sterile water, and an overnight incubation at room temperature in sterile water that contained approximately $0.1 \%$ commercial bleach. After three additional washings in sterile water, the seeds were transferred to petri dishes and incubated between moisturized filter paper in the dark, at $4^{\circ} \mathrm{C}$, for at least $24 \mathrm{~h}$ to promote germination. Then, the seeds were allowed to germinate for 2 days at $28^{\circ} \mathrm{C}$ in the same dishes. Seedlings with root lengths of approximately 1 to $2 \mathrm{~cm}$ were mounted on a curled wire in test tubes containing $25 \mathrm{ml}$ of Fåhraeus medium, according to López-Lara et al. (1995a), with one seed per tube. Alternatively, they were mounted on light or brown pots containing approximately $200 \mathrm{ml}$ of Fåhraeus liquid medium, if appropriate, containing $0.1 \mathrm{mg}$ of AVG per liter (Sigma, Bornhem, Belgium), with three to five
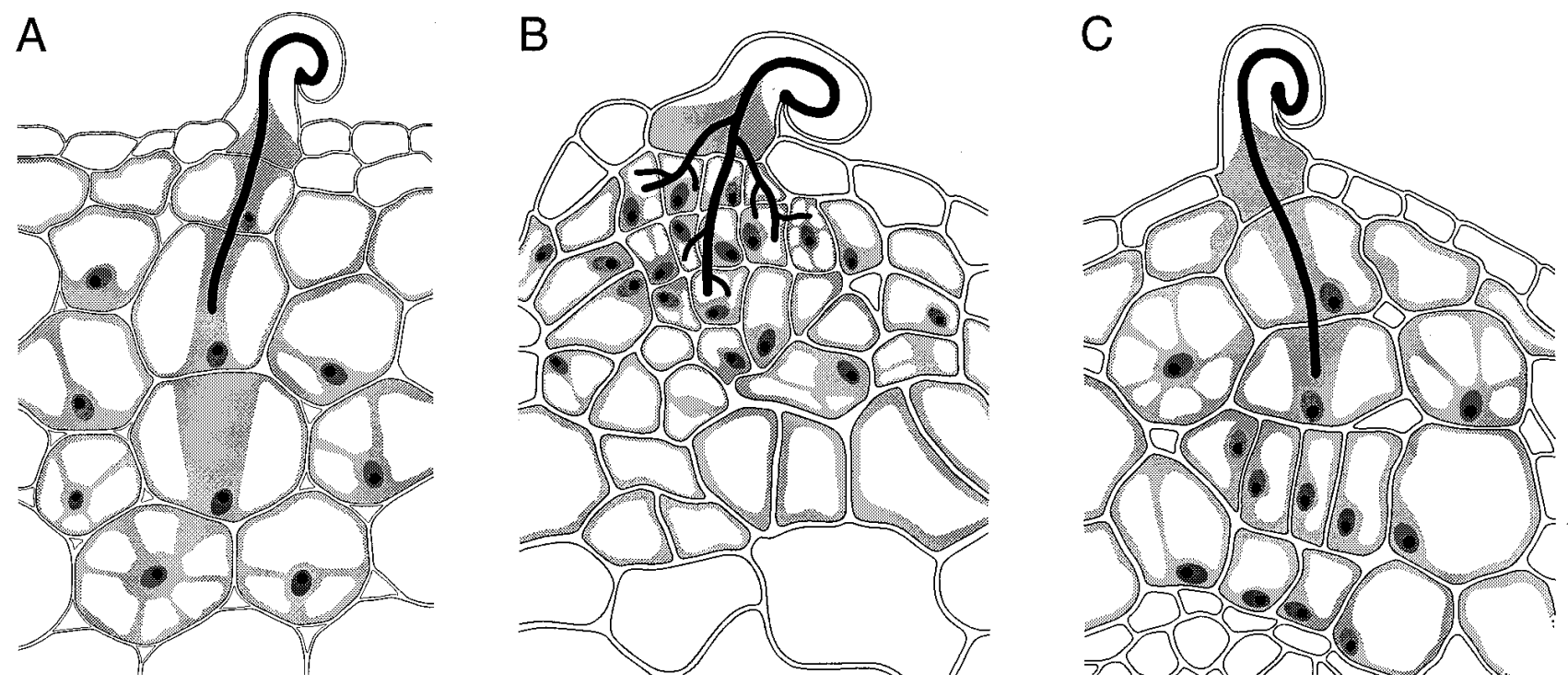

Fig. 4. Schematic comparison of the very early nodulation stages in the outer cortical root cells of $\mathbf{A}$, indeterminate-type and $\mathbf{B}$ and $\mathbf{C}$, determinate-type nodulating plants. Note that the drawing dimensions are adapted and thus not proportional to the actual dimensions of the respective plant roots. A, Development of cytoplasmic bridges in indeterminate-type nodulation as shown in earlier studies with pea and vetch (Bakhuizen 1988; Kijne 1992; Van Brussel et al 1992; Van Spronsen et al 1994). B, Development of a primordium in the outer cortical cell layer in the determinate-type nodulation plant common bean (this work). C, Development of cytoplasmic bridges and development of a primordium in the third cortical cell layer in the determinatetype nodulation plant L. japonicus (this work). 
seeds per pot. The seeds were inoculated with wild-type $R$. etli (strain CE3), grown in YMB medium (Hooykaas et al. 1977) for 3 days at $28^{\circ} \mathrm{C}$, optical density (OD) at $660 \mathrm{~nm}$ of $0.1(2 \times$ $10^{8}$ bacteria per $\left.\mathrm{ml}\right), 800 \mu \mathrm{l}$ per pot. The plants were then transferred to a growth chamber at $24^{\circ} \mathrm{C}$, with $16 \mathrm{~h}$ light $-8 \mathrm{~h}$ dark and relative humidity of $80 \%$. Roots of 5 to 7 days old, grown in test tubes or in brown pots with AVG, were processed for microscopy.

In order to test the sensitivity of the nodulation process to light (and indirectly to ethylene), nodulation tests were performed up to 12 days after inoculation in light or brown pots, with or without AVG, respectively.

\section{L. japonicus.}

L. japonicus seeds were surface sterilized in concentrated sulfuric acid (98\%) for $2 \mathrm{~min}$, and then washed thoroughly in a large quantity of water. Next, the seeds were treated with commercial bleach for $10 \mathrm{~min}$, washed three times in sterile water, and kept in sterile water overnight at room temperature. After three additional washings, the seeds were transferred to solidified Jensen medium (Vincent 1970) in a petri dish and incubated in the dark at $4^{\circ} \mathrm{C}$ for at least $24 \mathrm{~h}$ (dish upside down) to promote efficient and synchronous germination. Then, the petri dishes were transferred to $28^{\circ} \mathrm{C}$, and the seeds were allowed to germinate for approximately $24 \mathrm{~h}$. Seeds with roots of approximately $0.5 \mathrm{~cm}$ in length were selected and transferred to petri dishes with solidified Jensen medium (1.2\% Daishin agar; Brunschwig Chemicals, Amsterdam, The Netherlands), if appropriate, containing $0.1 \mathrm{mg}$ of AVG per liter. Each dish contained five to ten seedlings, which were inoculated with wild-type $M$. loti bacteria (strains NZP 2235 and NZP 2238, R7A, grown for 3 days in YMB medium at $\left.28^{\circ} \mathrm{C}, \mathrm{OD}_{660}=0.1\right)$ suspended in Jensen medium $\left(2 \times 10^{8}\right.$ bacteria per ml, approximately $10 \mu \mathrm{l}$ per plant). The dishes were sealed with Parafilm, with the lower half shielded from light, and placed in a vertical position in a growth chamber at $20^{\circ} \mathrm{C}$, with $16 \mathrm{~h}$ light-8 h dark and relative humidity of $70 \%$. Occasionally, specially made devices were used in which the roots could be shielded completely from light. In these cases, the medium did not contain AVG. Roots of 8 to 10 days old, grown shielded completely from light or in petri dishes in the presence of AVG, were processed for microscopy.

In order to test the sensitivity of the nodulation process to light (and indirectly to ethylene), nodulation tests were performed for up to 30 days after inoculation under conditions mentioned above for growth in petri dishes and with plants grown in the light, both with and without AVG.

\section{Spot inoculation of $L$. japonicus with LCOs.}

LCOs from $M$. loti strain R7A were extracted from 0.51 of bacteria culture and purified with high-pressure liquid chromatography (HPLC), as described in López-Lara et al. (1995b). The structures of the LCOs appeared to be identical to those produced by strain E1R, as reported in López-Lara et al. (1995b). All HPLC fractions containing LCOs were pooled and dissolved in $2 \mathrm{ml}$ of $60 \%$ acetonitrile. Afterward, $250 \mathrm{mg}$ of sterile quartz sand were coated with $2 \mathrm{ml}$ of a $5 \mathrm{mM}$ LCO solution and dried under a vacuum.

After sterilization, the L. japonicus seeds were allowed to germinate for 2 days until the roots were approximately $1 \mathrm{~cm}$ long. One to two grains of the LCO-coated sand were applied under the microscope, approximately at the middle of the roots. Roots at 4 to 6 days postinoculation (for very young stages) or up to 5 weeks postinoculation (for primordia) were processed for microscopy.

\section{Specimen preparation and microscopy.}

Inoculated roots of common bean and L. japonicus were fixed and prepared as described (Van Spronsen et al. 1994; Van Spronsen et al. 1995). Briefly, $1 \mathrm{~h}$ fixation in $2.5 \%$ glutaraldehyde and $2 \%$ paraformaldehyde were followed by 30 to 45 min of postfixation in $1 \%$ osmiumtetroxide, all in $0.1 \%$ sodium cacodylate buffer at room temperature. Then, a stepwise dehydration in ethanol was followed by a stepwise incubation in propylene oxide-Epon, followed by embedding and polymerization in Epon or a stepwise incubation in ethanolTechnovit and embedding and polymerization in a Technovit 7100 (Heraeus Kulzer, Wehrheim, Germany). Parts of the roots with very young infection zones and parts of the $L$. japonicus roots with LCO-activated zones were selected and transversely semithin sectioned serially with a glass knife on a LKB pyramitome. The sections were poststained with toluidine blue and studied with either a Leitz (Leica Microsystems, Wetzlar, Germany) or a Zeiss Axioplan 2 light microscope (Carl Zeiss, Thornwood, NY, U.S.A.) equipped with a DKC-5000 digital photo camera (Sony, Tokyo, Japan). Images were recorded, converted to grayscale, and corrected for brightness and contrast with Adobe Photoshop software (San Jose, CA, U.S.A.).

Additionally, young infection zones of common bean were ultrathin sectioned serially with a diamond knife (Diatome, Biel, Switzerland) on a Reichert-Jung ultramicrotome (Leica Microsystems), stained with uranyl acetate and lead citrate, and examined and photographed with a TEM 1010 electron microscope (JEOL, Peabody, MA, U.S.A.). Photographs were digitalized with Adobe Photoshop.

\section{ACKNOWLEDGMENTS}

We thank T. Tak for technical assistance, P. Hock for drawing Figure 4, and T. van Brussel for valuable discussions. We also thank J. ThomasOates, M. Olsthoorn, Y. van der Burgt, and A. Deelder for their help with the mass spectrometric analysis of the LCOs.

\section{LITERATURE CITED}

Bakhuizen, R. 1988. The plant cytoskeleton in the Rhizobium-legume symbiosis. Ph.D. thesis, Leiden University, Leiden, The Netherlands.

Brewin, N. J. 1991. Development of the legume root nodule. Annu. Rev. Cell Biol. 7:191-226.

Calvert, H. E., Pence, M. K., Pierce, M., Malik, N. S. A., and Bauer, W. D. 1984. Anatomical analysis of the development and distribution of Rhizobium infections in soybean roots. Can. J. Bot. 62:2375-2384.

Cermola, M., Fedorova, E., Taté, R., Riccio, A., Favre, R., and Patriarca, E. J. 2000. Nodule invasion and symbiosome differentiation during Rhizobium etli-Phaseolus vulgaris symbiosis. Mol. Plant-Microbe Interact. 13:733-741.

Fernández-López, M., Goormachtig, S., Gao, M., D’Haeze, W., Van Montagu, M., and Holsters, M. 1998. Ethylene-mediated phenotypic plasticity in root nodule development on Sesbania rostrata. Proc. Natl. Acad. Sci. USA 95:12724-12728.

Hirsch, A. M. 1992. Developmental biology of legume nodulation. New Phytol. 122:211-237.

Hooykaas, P. J. J., Klapwijk, P. M., Nuti, M. P., Schilperoort, R. A., and Rörsch, A. 1977. Transfer of the Agrobacterium tumefaciens Ti plasmid to avirulent agrobacteria and to rhizobia ex planta. J. Gen. Mi- 
crobiol. 98:477-484.

Kijne, J. W. 1992. The Rhizobium infection process. Pages 349-398 in: Biological Nitrogen Fixation. G. Stacey, R. H. Burris, and H. J. Evans, eds. Chapman and Hall, New York.

Libbenga, K. R., Van Iren, F., Bogers, R., and Schraag-Lamers, M. F. 1973. The role of hormones and gradients in the initiation of cortex proliferation and nodule formation in Pisum sativum L. Planta 114:2939.

Ligero, F., Poveda, J. L., Gresshoff, P. M., and Caba, J. M. 1999. Nitrateand inoculation-enhanced ethylene biosynthesis in soybean roots as a possible mediator of nodulation control. J. Plant Physiol. 154:482 488.

López-Lara, I. M., Van der Drift, K. M. G. M., Van Brussel, A. A. N., Haverkamp, J., Lugtenberg, B. J. J., Thomas-Oates, J. E., and Spaink, H. P. 1995a. Induction of nodule primordia on Phaseolus and Acacia by lipo-chitin oligosaccharide nodulation signals from broad-hostrange Rhizobium strain GRH2. Plant Mol. Biol. 29:465-477.

López-Lara, I. M., Van den Berg, J. D. J., Thomas-Oates, J. E., Glushka, J., Lugtenberg, B. J. J., and Spaink, H. P. 1995b. Structural identification of the lipo-chitin oligosaccharide nodulation signals of Rhizobium loti. Mol. Microbiol. 15:627-638.

Newcomb, W., Sippell, D., and Peterson, R. L. 1979. The early morphogenesis of Glycine max and Pisum sativum root nodules. Can. J. Bot. 57:2603-2616.

Ndoye, I., De Billy, F., Vasse, J., Dreyfus, B., and Truchet, G. 1994. Root nodulation of Sesbania rostrata. J. Bacteriol. 176:1060-1068.

Pacios Bras, C., Jordá, M. A., Wijfjes, A. H. M., Harteveld, M., Stuurman, N., Thomas-Oates, J. E., and Spaink, H. P. 2000. A Lotus japonicus nodulation system based on heterologous expression of the fucosyl transferase NodZ and the acetyl transferase NolL in Rhizobium leguminosarum. Mol. Plant-Microbe Interact. 13:475-479.

Rae, A. L., Bonfante-Fasolo, P., and Brewin, N. J. 1992. Structure and growth of infection threads in the legume symbiosis with Rhizobium leguminosarum. Plant J. 2:385-395.

Ridge, R. W., and Rolfe, B. G. 1986. Sequence of events during the infection of the tropical legume Macroptilium atropurpureum Urb. by the broad-host-range, fast-growing Rhizobium ANU240. J. Plant Physiol. 122:121-137.

Szczyglowski, K., Shaw, R. S., Wopereis, J., Copeland, S., Hamburger, D., Kasiborski, B., Dazzo, F. B., and De Bruijn, F. J. 1998. Nodule organogenesis and symbiotic mutants of the model legume Lotus japonicus. Mol. Plant-Microbe Interact. 11:684-697.

Schmidt, J. S., Harper, J. E., Hoffman, T. K., and Bent, A. F. 1999. Regulation of soybean nodulation independent of ethylene signaling. Plant Physiol. 119:951-959.
Taté, R., Patriarca, E. J., Riccio, A., Defez, R., and Iaccarino, M. 1994. Development of Phaseolus vulgaris root nodules. Mol. Plant-Microbe Interact. 7:582-589.

Timmers, A. C. J., Auriac, M. C., and Truchet, G. 1999. Refined analysis of early symbiotic steps of the Rhizobium-Medicago interaction in relationship with microtubular cytoskeleton rearrangements. Development 126:3617-3628

Turgeon, B. G., and Bauer, W. D. 1982. Early events in the infection of soybean by Rhizobium japonicum. Time course and cytology of the initial infection process. Can. J. Bot. 60:152-161.

Turgeon, B. G., and Bauer, W. D. 1985. Ultrastructure of the infectionthread development during the infection of soybean by Rhizobium japonicum. Planta 163:328-349.

Van Brussel, A. A. N., Tak, T., Wetselaar, A., Pees, E. and Wijffelman, C. A. 1982. Small leguminosae as test plants for nodulation of Rhizobium leguminosarum and other rhizobia and agrobacteria harbouring a leguminosarum Sym-plasmid. Plant Sci. Lett. 27:317-325.

Van Brussel, A. A. N., Bakhuizen, R., Van Spronsen, P. C., Spaink, H. P., Tak, T., Lugtenberg, B. J. J., and Kijne, J. W. 1992. Induction of preinfection thread structures in the leguminous host plant by mitogenic lipo-oligosaccharides of Rhizobium. Science 257:70-72.

Vandenbosch, K. A., Noel, K. D., Kaneko, Y., and Newcomb, E. H. 1985. Nodule initiation elicited by noninfective mutants of Rhizobium phaseoli. J. Bacteriol. 162:950-959.

Van Spronsen, P. C., Bakhuizen, R., Van Brussel, A. A. N., and Kijne, J. W. 1994. Cell wall degradation during infection thread formation by the root nodule bacterium Rhizobium leguminosarum is a two-step process. Eur. J. Cell Biol. 64:88-94.

Van Spronsen, P. C., Van Brussel, A. A. N., and Kijne, J. W. 1995. Nod factors produced by Rhizobium leguminosarum biovar viciae induce ethylene-related changes in root cortical cells of Vicia sativa ssp. $n i$ gra. Eur. J. Cell. Biol. 68:463-469.

Vincent, J. M. 1970. A Manual for the Practical Study of Root-Nodule Bacteria: I.B.P. Handbook No. 15. Blackwell Scientific Publications, Oxford, U.K.

Yang, W. C., De Blank, C., Meskiene, I., Hirt, H., Bakker, J., Van Kammen, A., Franssen, H., and Bisseling, T. 1994. Rhizobium Nod factors reactivate the cell cycle during infection and nodule primordium formation, but the cycle is only completed in primordium formation. Plant Cell 6:1415-1426.

Zaat, S. A. J., Van Brussel, A. A. N., Tak, T., Lugtenberg, B. J. J., and Kijne, J. W. 1989. The ethylene-inhibitor aminoethoxyvinylglycine restores normal nodulation by Rhizobium leguminosarum biovar viciae on Vicia sativa subsp. nigra by suppressing the "thick and short roots" phenotype. Planta 177:141-150. 